\title{
NDVI-Based Vegetation Change in Inner Mongolia from 1982 to 2006 and Its Relationship to Climate at the Biome Scale
}

\author{
Linghui Guo, ${ }^{1,2}$ Shaohong Wu, ${ }^{1}$ Dongsheng Zhao, ${ }^{1}$ Yunhe Yin, \\ Guoyong Leng, ${ }^{1,2}$ and Qingyu Zhang ${ }^{1,2}$ \\ ${ }^{1}$ Institute of Geographic Sciences and Natural Resources Research, Chinese Academy of Sciences, Beijing 100101, China \\ ${ }^{2}$ University of Chinese Academy of Sciences, Beijing 100049, China \\ Correspondence should be addressed to Dongsheng Zhao; zhaods@igsnrr.ac.cn
}

Received 19 November 2013; Revised 25 January 2014; Accepted 27 January 2014; Published 3 March 2014

Academic Editor: Dong Jiang

Copyright (C) 2014 Linghui Guo et al. This is an open access article distributed under the Creative Commons Attribution License, which permits unrestricted use, distribution, and reproduction in any medium, provided the original work is properly cited.

Based on the normalized difference vegetation index (NDVI), we analyzed vegetation change of the six major biomes across Inner Mongolia at the growing season and the monthly timescales and estimated their responses to climate change between 1982 and 2006. To reduce disturbance associated with land use change, those pixels affected by land use change from the 1980s to 2000s were excluded. At the growing season scale, the NDVI increased weakly in the natural ecosystems, but strongly in cropland. Interannual variations in the growing season NDVI for forest was positively linked with potential evapotranspiration and temperature, but negatively correlated with precipitation. In contrast, it was positively correlated with precipitation, but negatively related to potential evapotranspiration for other natural biomes, particularly for desert steppe. Although monthly NDVI trends were characterized as heterogeneous, corresponding to monthly variations in climate change among biome types, warming-related NDVI at the beginning of the growing season was the main contributor to the NDVI increase during the growing season for forest, meadow steppe, and typical steppe, but it constrained the NDVI increase for desert steppe, desert, and crop. Significant one-month lagged correlations between monthly NDVI and climate variables were found, but the correlation characteristics varied greatly depending on vegetation type.

\section{Introduction}

Climate change has resulted in a significant effect on vegetation dynamics during the past decades [1-4] due to the associated alterations to biogeochemical processes, such as plant photosynthesis, respiration, and mineralization of soil organic matter [5-7], and these changes are projected to be enhanced in the future years [8-12].

A number of previous studies have investigated annual variations in vegetation and their responses to climate changes using the normalized difference vegetation index (NDVI), a reliable indicator of vegetation change, at both regional and global scales [13-21]. However, less attention has been paid to vegetation change (NDVI) and its relationships with climatic factors over shorter timescales [22, 23]. For many ecological and agricultural issues, finer temporal resolution is more relevant [23]. Besides, the magnitude of the monthly NDVI and its change over time are vital indicators of the contribution of vegetation change in different months to annual plant growth [16]. Furthermore, many recent studies have focused mainly on the influence of precipitation and mean temperature on vegetation change, and the important role of other factors has been neglected, such as maximum and minimum temperature and potential evapotranspiration, which also exert considerable influence on patterns of vegetation growth [24-27]. In addition, increasing numbers of studies have confirmed the effect of interannual climate variability on vegetation change, which varies considerably depending on the ecogeographical region and vegetation types [16, 2830]. Therefore, developing a better understanding of the effect of climate on vegetation growth at the biome scale is of some significance.

The Inner Mongolia Autonomous Region consists of vast forests and the largest grazing area in China and is considered to be an important timber and livestock region in China [31]. As an ecotransition zone, it has a sharp rainfall-temperature 


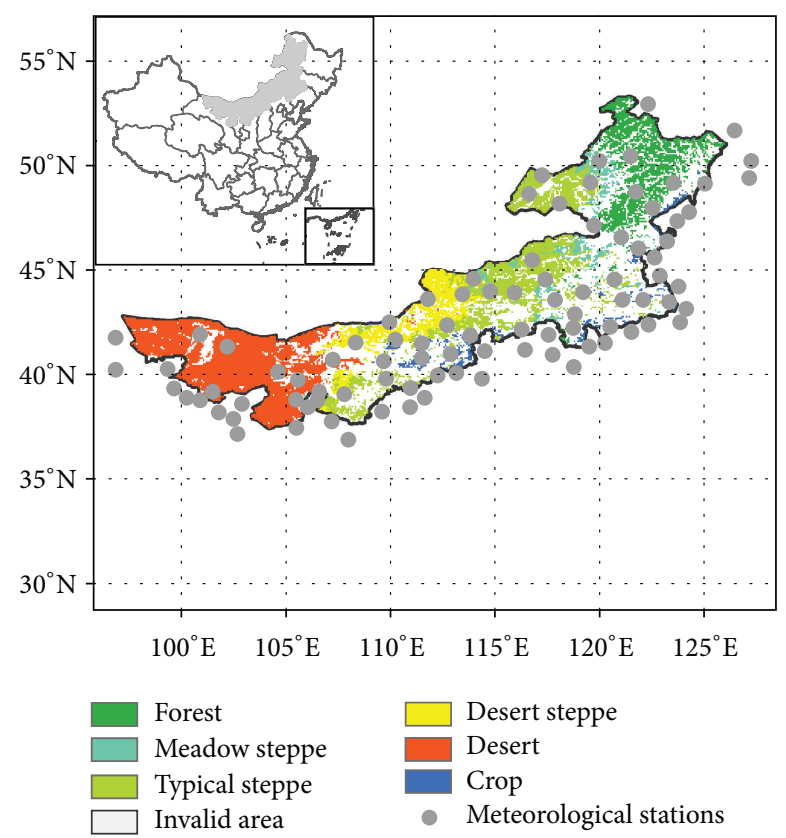

FIGURE 1: The spatial distribution of vegetation types and the 92 meteorological stations used in this study. The inset map indicates the location of the study area in China.

gradient from the southwest to northeast, where vegetation growth is likely to be highly sensitive to climate change [32]. Over recent decades, it has experienced dramatic climate change, which has been more pronounced than most other areas in China [33-36]. The study of climate-related vegetation dynamics here is of fundamental importance to improve our understanding of the mechanisms in the relationship between climate change and vegetation change, and also critical to policy-making for regional adaptation plans. The objective of the present study is to investigate how and why vegetation change has occurred in Inner Mongolia over the past 25 years. Firstly, we examined changes in the growing season NDVI, and variations in NDVI for each month during the growing season to gain further insights into its contribution to the changes in growing season NDVI during the period of 1982-2006, and we further investigated the relationships between climatic factors and NDVI at the growing season and monthly scales, based on vegetation types.

\section{Data and Methods}

2.1. Study Area. Inner Mongolia is situated in the northern part of China and stretches from approximately $37^{\circ} \mathrm{N}$ to $53^{\circ} \mathrm{N}$ and $97^{\circ} \mathrm{E}$ to $126^{\circ} \mathrm{E}$, a total area of nearly 1.2 million $\mathrm{km}^{2}$ (Figure 1). The region is dominated by monsoon climate pattern that are controlled by continental Eurasian high and low pressure cells. During the summer, warm and humid air from the Pacific contributes to high temperatures and variable rainfall. In the winter, the region is affected by strong, dry, and cold northwesterly winds regulated by the Siberian-Mongolian atmospheric high pressure cell [31, 37]. The climate is characterized by an increase in precipitation and a decrease in temperature from southwest to northeast [38]. From southwest to northeast, it can be divided into four major zones [39]. The medium temperate arid region in the southwest is dominated by the desert biome. The medium temperate semiarid region occupying most of the central area (approximately $40^{\circ} \mathrm{N}$ to $50^{\circ} \mathrm{N}$ latitude and $110^{\circ} \mathrm{E}$ to $120^{\circ} \mathrm{E}$ longitude) is dominated by steppe and fragmented areas of cropland. Finally, the cold temperate humid and medium temperate subhumid regions, occurring mainly in the northeast, are dominated by the forest biome. In this study, we focused on the cultivated and five of the major natural vegetation types of Inner Mongolia: cropland, forest, meadow steppe, typical steppe, desert steppe, and desert. We selected these biomes because they are the dominant vegetation types and follow the rainfall-temperature gradient from the southwest to the northeast.

2.2. Dataset. Vegetation change was identified using NDVI data developed by the global inventory monitoring and modeling studies (GIMMS) group and derived from the NOAA/AVHRR land dataset for the period 1982-2006 (available at ftp://ftp.glcf.umiacs.umd.edu/glcf/GIMMS/), which has a resolution of $8 \mathrm{~km}$ and an interval of 15 days. The data calibrated to eliminate noise from solar angle and sensor errors has been widely used in analyzing the long-term trends in vegetation cover and activity in China [16, 31, 40]. To further decrease the effects of atmospheric and aerosol scattering, we developed a monthly NDVI data using maximum value composite (MVC) method for each month, as previous study [41]. The growing season was defined as April to October [42-44], and the growing season NDVI data were obtained by averaging these monthly NDVI data during the period of April-October for each year.

The climate variables used were the monthly precipitation amount $(P)$, mean temperature $\left(T_{\text {mean }}\right)$, maximum temperature $\left(T_{\max }\right)$, minimum temperature $\left(T_{\min }\right)$, and potential evapotranspiration (PET). These data were interpolated using ANUSPLIN 4.3 software (http://fennerschool.anu.edu.au/research/products) at a resolution of $8 \mathrm{~km}$, based on 92 climatic stations of the China Meteorological Administration in or around Inner Mongolia (Figure 1). To check the performance of the ANUSPLIN 4.3 interpolation for Inner Mongolia, the monthly data in the year of 2000 were interpolated by using ANUSPLIN 4.3, based on observational data from 82 of the 92 climate stations. Then, observational monthly data from the remaining 10 climate stations were compared with corresponding pixel values obtained from the interpolation data in 2000. The coefficients of determination $\left(R^{2}\right)$ between the interpolations and observations indicated that the simulated monthly $T_{\text {mean }}, T_{\max }, T_{\min }$, PET, and $P$ fitted the observed values reasonably with average $R^{2}$ of $0.99,0.98,0.98,0.81$, and 0.79 , respectively. PET ( $\mathrm{mm} \mathrm{day}^{-1}$ ) was calculated using an improved United Nations Food and Agriculture Organization (FAO) Penman-Monteith method [45]:

$$
\operatorname{PET}=\frac{0.408 \delta\left(R_{n}-G\right)+\gamma(900 /(T+273)) U_{2}\left(e_{s}-e_{a}\right)}{\delta+\gamma\left(1+0.34 U_{2}\right)},
$$


where $\delta$ is the slope of the saturation vapor pressure versus air temperature curve $\left(\mathrm{kPa}^{\circ} \mathrm{C}^{-1}\right), R_{n}$ is net solar radiation at the plant surface $\left(\mathrm{MJ} \mathrm{m}^{-2} \mathrm{day}^{-1}\right), G$ is soil heat flux density $\left(\mathrm{MJ} \mathrm{m}^{-2}\right.$ day $\left.^{-1}\right), \gamma$ is the psychrometric constant $\left(\mathrm{kPa}^{\circ} \mathrm{C}^{-1}\right), T$ is mean air temperature at a height of $2 \mathrm{~m}\left({ }^{\circ} \mathrm{C}\right)$, $U_{2}$ is mean wind speed at a height of $2 \mathrm{~m}\left(\mathrm{~m} \mathrm{~s}^{-1}\right), e_{s}$ is saturation vapor pressure $(\mathrm{kPa})$, and $e_{a}$ is actual vapor pressure $(\mathrm{kPa})$.

The information on distribution of vegetation types was obtained from vegetation map of China with a scale of $1: 1000000$ [46]. Based on this map and the criteria of Editorial Board of Rangeland Resources of China, 1996 [47], vegetation types in Inner Mongolia were further grouped into cropland, forest, meadow steppe, typical steppe, desert steppe, and desert. Then, they were converted to grid maps with a resolution of $8 \mathrm{~km}$, which corresponds to that of the NDVI data.

Digital land-use maps of the scale 1:100000 in 1980s and 2000, provided by the Data Center for Resources and Environmental Sciences of the Chinese Academy of Sciences (http://www.resdc.cn/), were used to identify land-use change in 1980s to 2000s. These data based on the Landsat Thematic Mapper (TM)/Enhanced Thematic Mapper (ETM)/Multispectral Scanner System (MSS) images/landuse survey have been proved to be of high accuracy and could better meet the needs of studies on land-use change at regional or national scales $[48,49]$.

2.3. Method. To remove biases related to the effects of landuse change on NDVI values, pixels affected by land-use change during the study period were excluded. Specifically, we extracted each land-use type for the two periods and converted them to a grid format with a resolution of $8 \mathrm{~km}$, respectively, and then masked them to identify those pixels with no land-use change during the 1980s and 2000s. These pixels were then selected to mask the vegetation types. Results of the vegetation survey are presented in Figure 1.

Linear time trends were evaluated using the ordinary least squares method for the NDVI and climate variables over the growing season and monthly timescales for each vegetation type, and the Pearson correlation coefficients between the NDVI and climatic variables were also calculated to determine the extent of the relationship between them.

\section{Results and Discussion}

3.1. Changes in Growing Season and Monthly NDVI. From 1982 to 2006, the climate records showed warming and drying trends across the forest, meadow steppe, typical steppes, and crop regions, while they showed wetting and warming in the desert steppes and desert areas (Figure 2). The growing season NDVI for all biomes increased over the past 25 years, with the magnitudes differing greatly by vegetation type (Figure 2). The cultivated ecosystem showed a significant increasing trend, with an average increment of $0.0016 \mathrm{yr}^{-1}(P<0.01)$. In comparison, the natural ecosystems increased only slightly and weakly, with the largest increase $\left(0.0005 \mathrm{yr}^{-1} ; P=0.50\right)$ occurring in the forest region and the lowest $\left(0.00001 \mathrm{yr}^{-1} ; P=0.90\right)$ in the desert. Such an increase in the NDVI indicates that vegetation activity in Inner Mongolia is strengthening during the study period, to some extent. This is generally consistent with previous studies, which demonstrated that the overall state of Inner Mongolia's vegetation developed favorably in the past years $[40,43,50,51]$.

In order to more clearly examine the contribution of each month to the growing season NDVI trend, Figure 3 shows the changes in the trend of monthly NDVI over the period of 1982-2006. For the forest, the monthly NDVI trend at the beginning and end of the growing season (i.e., May and September) increased much larger than that in other months, with an increase of $0.0028 \mathrm{yr}^{-1}\left(R^{2}=0.05, P=0.26\right)$ and $0.0038 \mathrm{yr}^{-1}\left(R^{2}=0.18, P<0.05\right)$, respectively. In contrast, there was a marked decrease from June to August, with a minimum rate of $-0.002 \mathrm{yr}^{-1}\left(R^{2}=0.14, P<0.1\right)$ in July (Figure 3(a)-N). This is in agreement with the result from Mao et al. [52], who found that the larger NDVI increase was in May and September in northeast China, at the similar latitude as this region [52]. By comparison, NDVI values for most growing season months tended to increase for the steppes. The largest trends occurred in April and August, with annual rates of $0.0010 \mathrm{yr}^{-1}\left(R^{2}=0.23, P<0.05\right)$ and $0.0013 \mathrm{yr}^{-1}\left(R^{2}=0.08, P=0.15\right)$, respectively, for the meadow steppe (Figure 3(b)- $N), 0.0009 \mathrm{yr}^{-1}\left(R^{2}=0.36, P<0.01\right)$ and $0.0017 \mathrm{yr}^{-1}\left(R^{2}=0.08, P=0.17\right)$, respectively, for the typical steppe (Figure $3(\mathrm{c})-N)$, and $0.0002 \mathrm{yr}^{-1}\left(R^{2}=0.02, P=0.56\right)$ and $0.001 \mathrm{yr}^{-1}\left(R^{2}=0.03, P=0.39\right)$, respectively, for the desert steppe (Figure 3(d)-N). However, the monthly NDVI for the desert exhibited a noticeably different pattern from the other biomes, with the larger increases of $0.0002 \mathrm{yr}^{-1}$ $\left(R^{2}=0.03, P=0.41\right)$ and $0.0001 \mathrm{yr}^{-1}\left(R^{2}=0.03, P=\right.$ $0.43)$ in September and October, respectively, while that in July decreased significantly by $-0.0003 \mathrm{yr}^{-1}\left(R^{2}=0.10, P=\right.$ 0.12 ) (Figure $3(\mathrm{e})-N$ ). For thecropland, monthly NDVI rose significantly in July, August, and September, which played an important role in the growing season NDVI trend. In contrast, monthly NDVI decreased strongly from April to June (Figure 3(f)-N). This could partly be due to the fact that the dominant crop type have been changed from spring wheat to maize [53]. Specifically, the area of spring wheat declined from about 1.1 million hectares in 1990 to 0.4 million hectares in 2006, while that of maize increased greatly from 0.8 million hectares to about 2 million hectares [53, 54].

\subsection{The Response of Growing Season NDVI to Climate Change.} Table 1 illustrates the correlations between climatic variables and NDVI for the different vegetation types at the growing season scale. For the forest, the growing season NDVI positively correlated with the corresponding PET $(R=0.53$, $P<0.01)$ and temperature, especially $T_{\max }(R=0.39, P<$ $0.1)$, but related only weakly and negatively to $P(R=-0.30$, $P=0.16)$. Nevertheless, lower growing season NDVI values in 1984, 1993, 1998, and 2003 corresponded well with higher $P$ values (Figure 1(a)). To further analyze the relationship between growing season NDVI and peak precipitation, we 

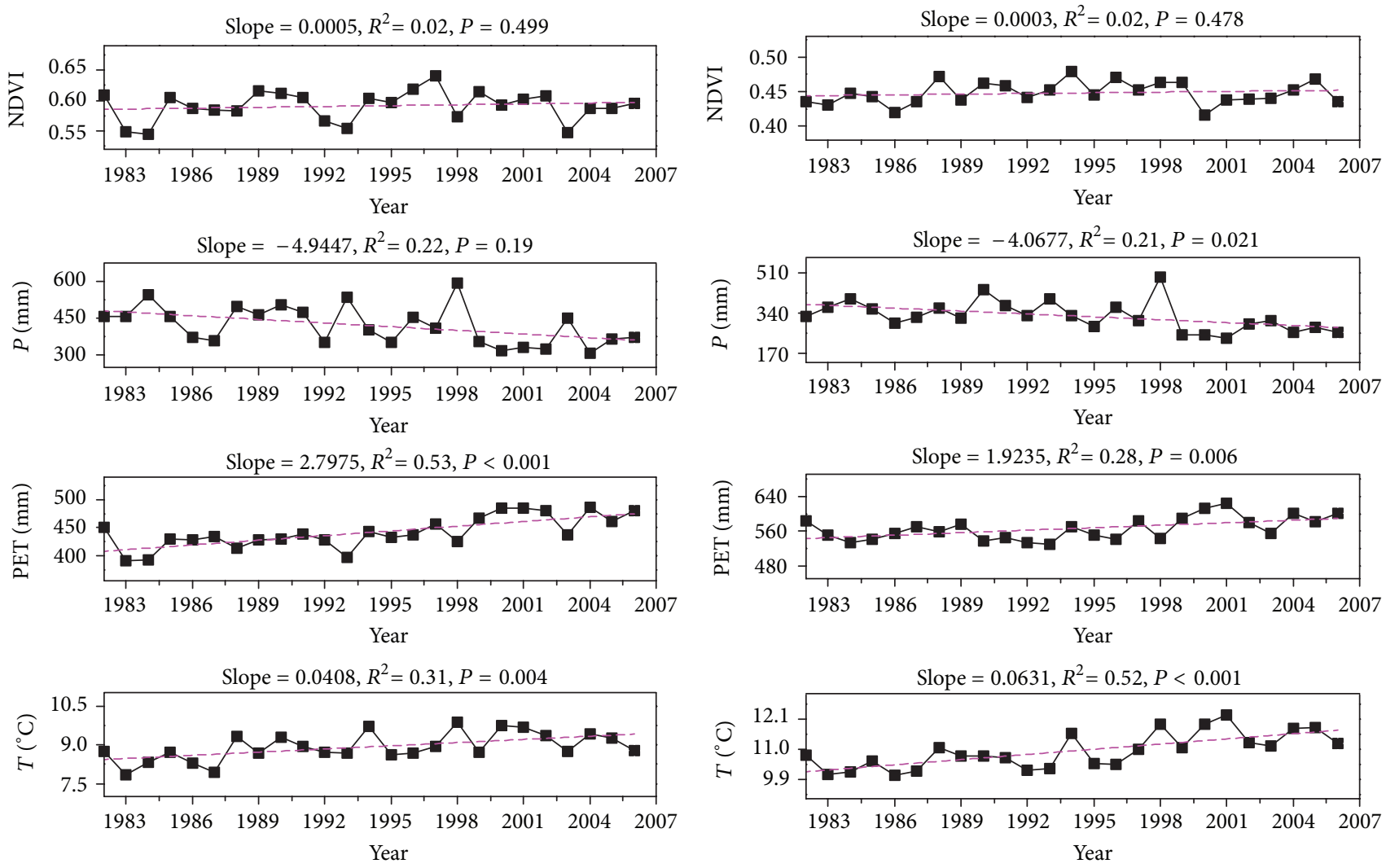

(a)

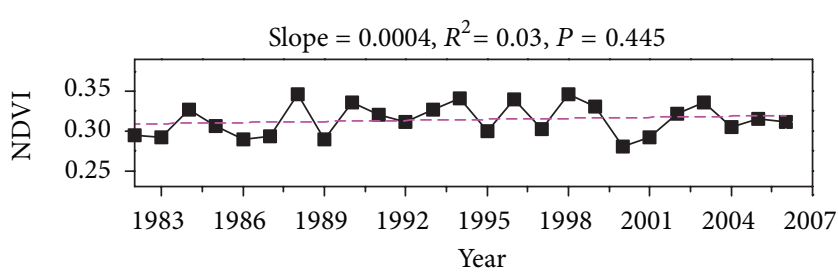

(b)
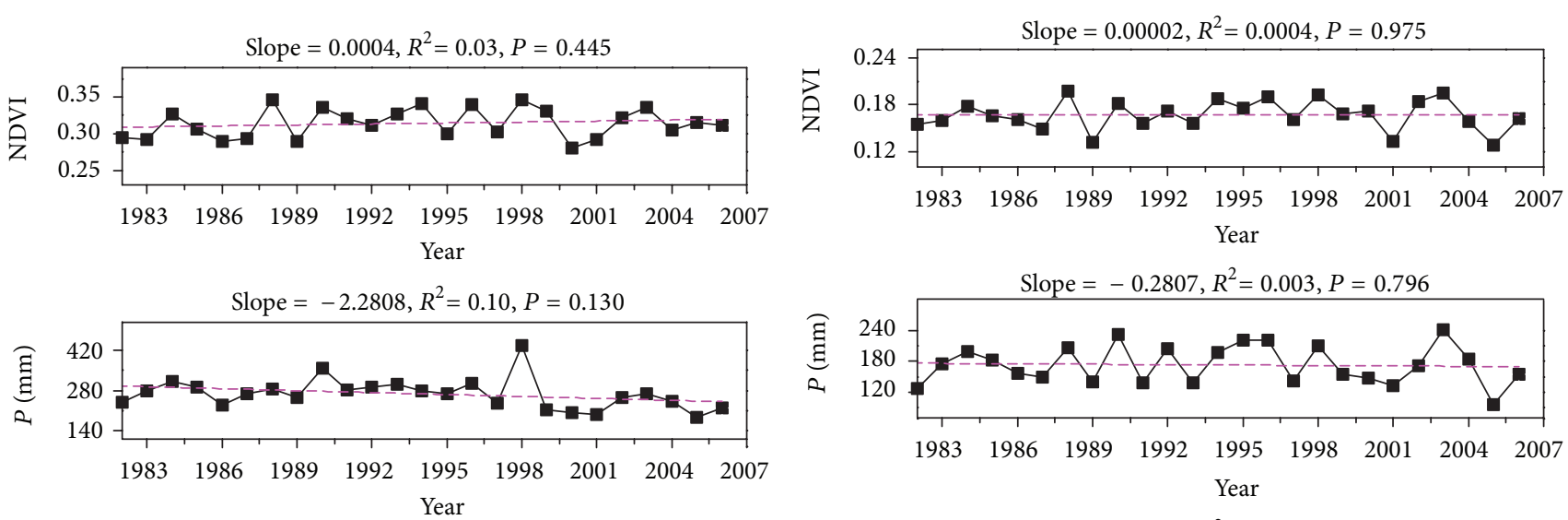

Slope $=0.5645, R^{2}=0.02, P=0.483$

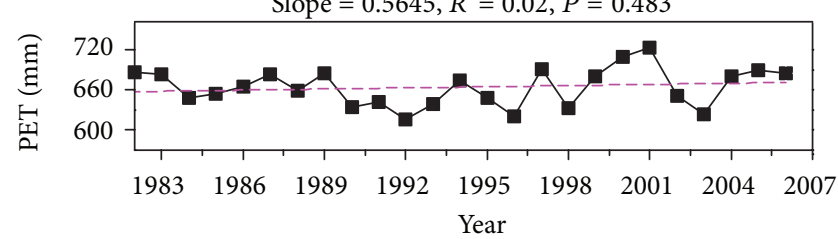

Slope $=-0.8451, R^{2}=0.04, P=0.367$

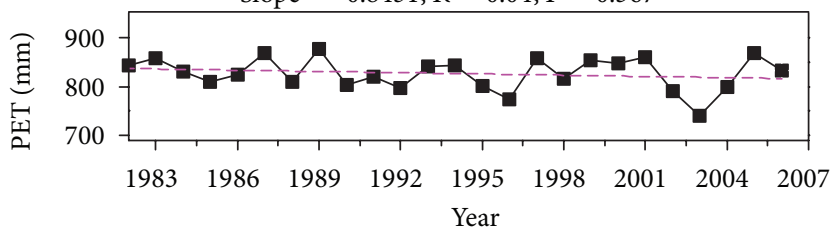

Slope $=0.0667, R^{2}=0.54, P<0.001$

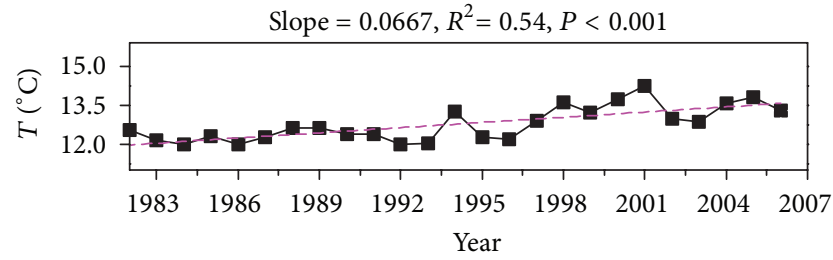

Slope $=0.0693, R^{2}=0.55, P<0.001$

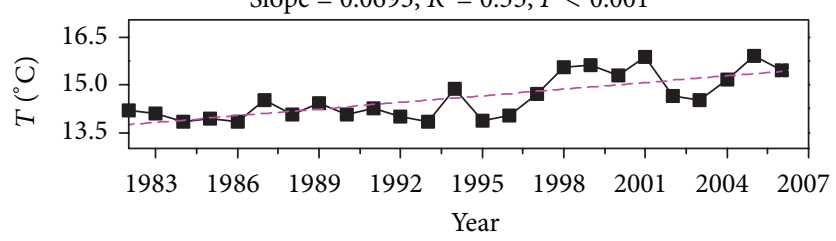

(d)

FIgUre 2: Continued. 


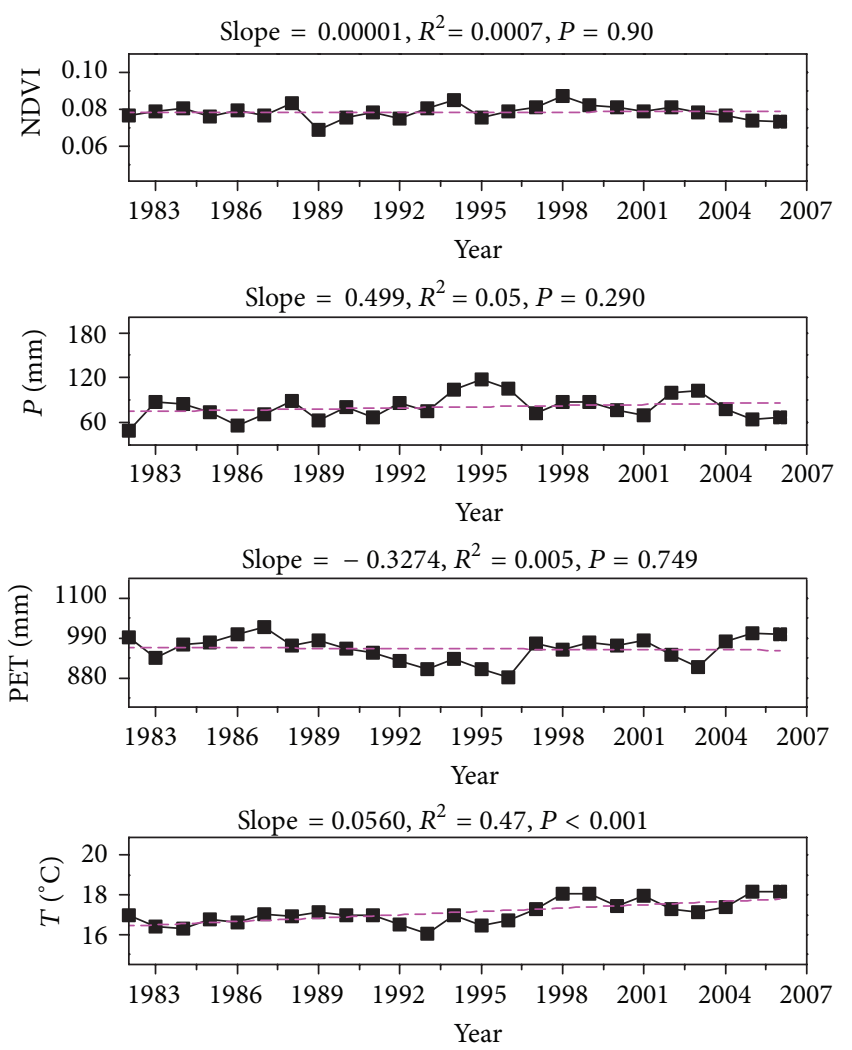

(e)
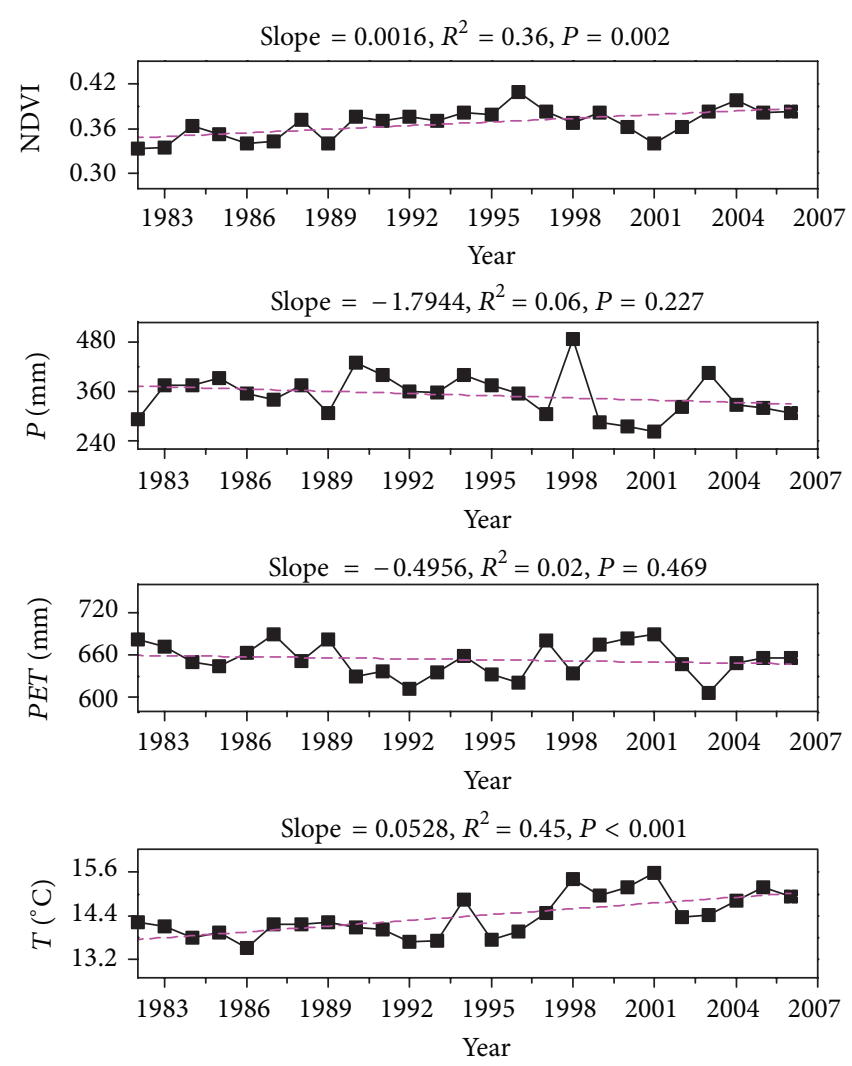

(f)

FIGURE 2: Interannual variations of growing season mean NDVI, growing season $P$, growing season PET, and growing season $T_{\text {mean }}$ for (a) forest, (b) meadow steppe, (c) typical steppe, (d) desert steppe, (e) desert, and (f) cropland during the period 1982-2006.

TABLE 1: Correlation between growing season NDVI and corresponding climate variables for different biomes: growing season $P$, growing season PET, and growing season $T_{\text {mean }}, T_{\max }$, and $T_{\min }$.

\begin{tabular}{|c|c|c|c|c|c|c|}
\hline \multirow{2}{*}{ Climate variables } & \multicolumn{6}{|c|}{ Correlation coefficient } \\
\hline & Forest & Meadow steppe & Typical steppe & Desert steppe & Desert & Crop \\
\hline$P$ & -0.30 & $0.38^{*}$ & $0.58^{* * *}$ & $0.84^{* * *}$ & $0.35^{*}$ & 0.18 \\
\hline PET & $0.53^{* * *}$ & -0.27 & $-0.63^{* * *}$ & $-0.71^{* * *}$ & -0.22 & $-0.58^{* * *}$ \\
\hline$T_{\text {mean }}$ & 0.29 & 0.20 & -0.04 & -0.29 & 0.02 & 0.12 \\
\hline$T_{\max }$ & $0.39^{*}$ & 0.073 & -0.13 & -0.33 & 0.09 & 0.03 \\
\hline$T_{\min }$ & 0.01 & $0.36^{*}$ & 0.16 & -0.10 & -0.02 & 0.26 \\
\hline
\end{tabular}

calculated the correlation coefficients between precipitation amounts more than $455 \mathrm{~mm}$ (a little above the mean) during the growing season and corresponding NDVI value, and a significant negative correlation was observed $(R=-0.55$, $P<0.1)$. These findings suggest that increases in either temperature or potential evapotranspiration boost forest growth, whereas too much precipitation depresses it. In forest dominated areas (cold temperate humid and medium temperate subhumid regions), a negative correlation between the growing season NDVI and precipitation, especially in wetter years, can be attributed to increased cloud cover and the consequent decrease in solar radiation and temperature [52]. In contrast, a positive relationship was observed between the growing season NDVI and temperature, which is broadly consistent with the results of previous studies performed in northern middle-high latitudes [19, 40, 55]. This may be a consequence of increased temperatures lengthening the growing period and enhancing photosynthesis, while also reducing the negative effect derived from excessive precipitation in summer [56-58].

In contrast, there was a significant positive correlation between growing season NDVI and $P$ for meadow steppes, typical steppes, desert steppes, and desert $(R=0.38, P<$ $0.1 ; R=0.58, P<0.01 ; R=0.84, P<0.01$; and $R=$ $0.35, P<0.1$, resp.), but a negative correlation between growing season NDVI and PET, especially for the typical 

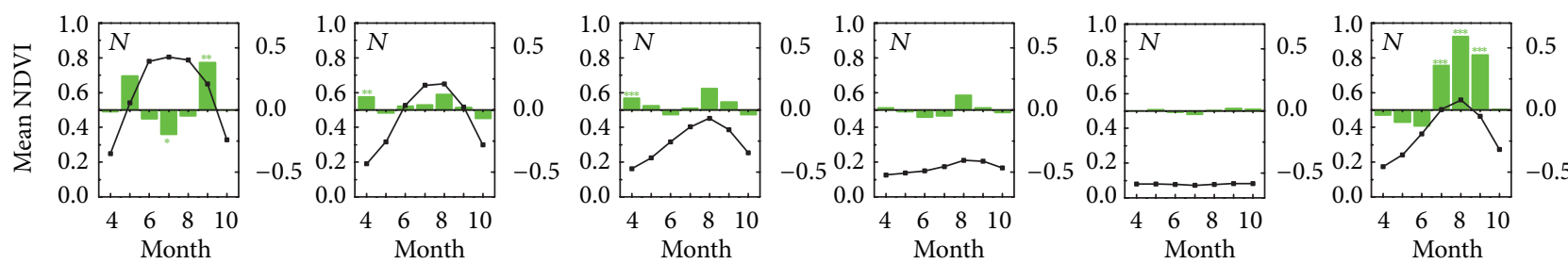

1)
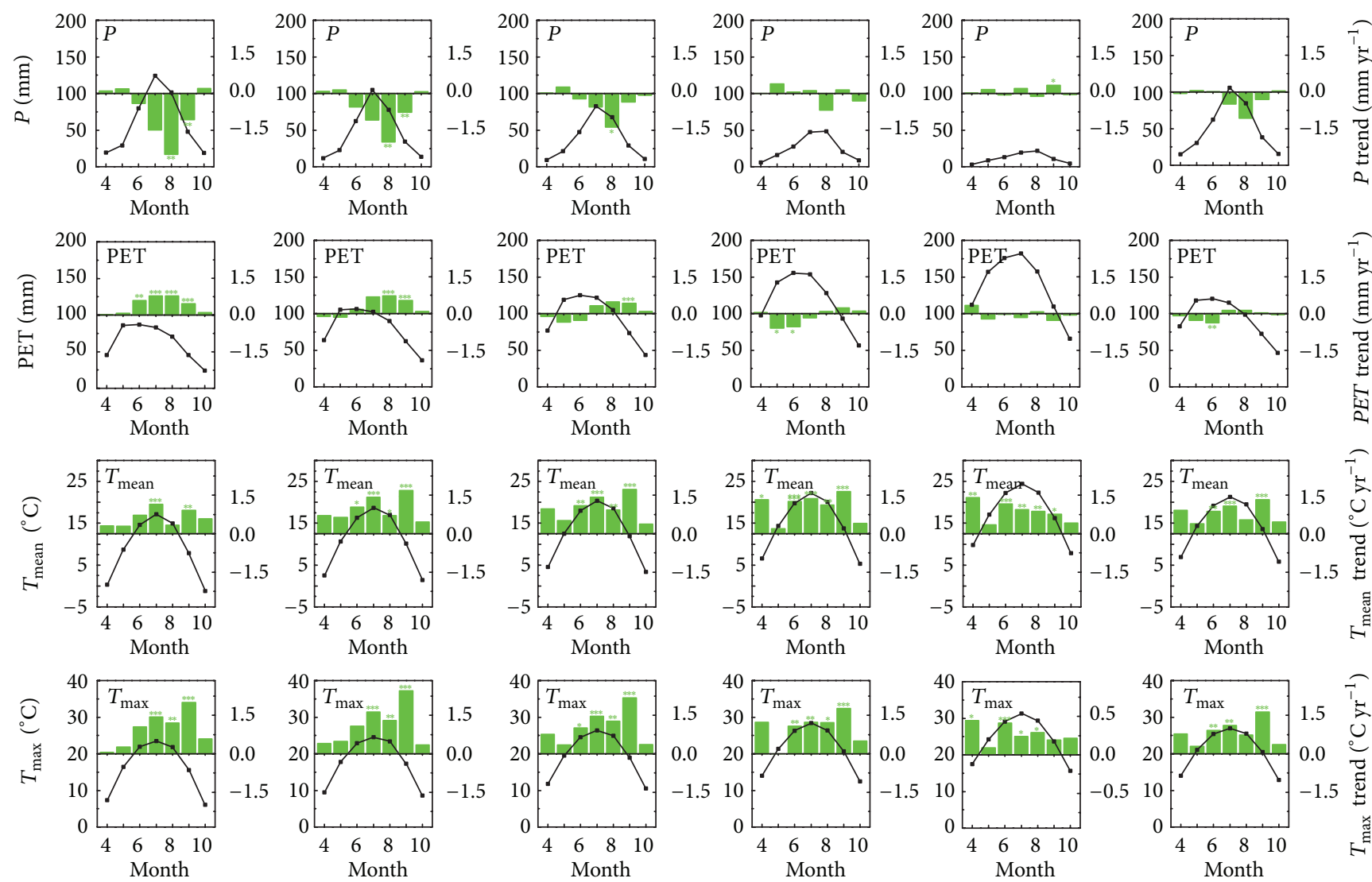

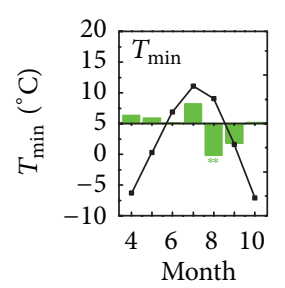

(a)

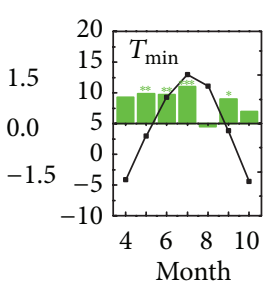

(b)

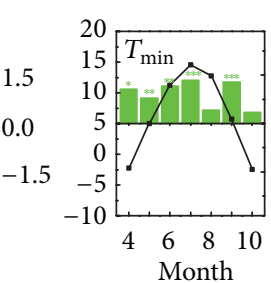

(c)

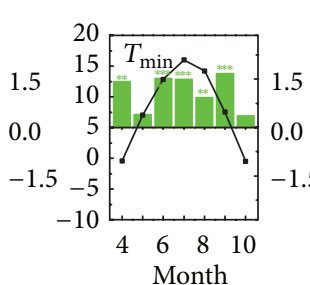

(d)

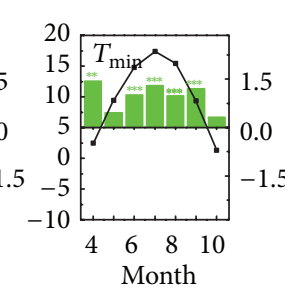

(e)

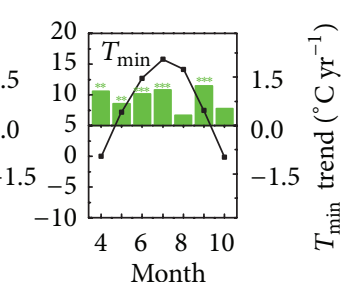

(f)

FIGURE 3: Variation in monthly NDVI and climatic variables during growing season over the 25 years for the six vegetation types: (a) forest, (b), meadow steppe, (c) typical steppe, (d), desert steppe, (e) desert, and (f) cropland. Monthly $P$, monthly PET, and monthly $T_{\text {mean }}, T_{\text {max }}$, and $T_{\min }$. The green bars denote the trends, and black lines represent the mean values. $* * *, * *$, and $*$ indicate $P<0.01, P<0.05$, and $P<0.1$, respectively.

and desert steppes $(R=-0.63, P<0.01$; and $R=$ $-0.71, P<0.01$, resp.), implying that water may be the key factor controlling grass growth. In addition, growing season NDVI was also positively related to temperature for the meadow steppe, especially to $T_{\min }(R=0.36, P<$ 0.1 , indicating that an increase in temperature can also enhance meadow steppe growth. The steppes and desert biomes are dominated by a medium temperate semiarid and arid climate, and the growing season NDVI rose as precipitation increased, which agrees with previous findings $[28,44,59]$. These relationships strengthened from meadow steppe to typical steppe and desert steppe, but then weakened to desert, which tends to confirm the general viewpoint that a threshold exists around which vegetation growth is most sensitive to water supply, and below or above which the relationship weakens $[29,60]$. Grass in subarid and arid regions is predominantly influenced by precipitation: the more precipitation, the more vegetation growth. However, 
TABLE 2: Correlation coefficients between monthly mean NDVI and $P$, PET, $T_{\text {mean }}, T_{\max }$, and $T_{\min }$ in the same month for different vegetation types.

\begin{tabular}{|c|c|c|c|c|c|c|c|c|}
\hline \multirow{2}{*}{ Vegetation types } & \multirow{2}{*}{ Climate variables } & \multicolumn{7}{|c|}{ Correlation coefficient } \\
\hline & & 4 & 5 & 6 & 7 & 8 & 9 & 10 \\
\hline \multirow{5}{*}{ Forest } & $P$ & -0.22 & -0.25 & 0.08 & $-0.38^{*}$ & $-0.44^{* *}$ & -0.31 & 0.06 \\
\hline & PET & $0.74^{* * *}$ & $0.43^{* *}$ & 0.13 & $0.35^{*}$ & $0.55^{* * *}$ & $0.60^{* * *}$ & -0.05 \\
\hline & $T_{\text {mean }}$ & $0.48^{* *}$ & $0.74^{* * *}$ & 0.23 & -0.21 & 0.32 & -0.02 & 0.27 \\
\hline & $T_{\max }$ & $0.55^{* * *}$ & $0.69^{* * *}$ & 0.22 & 0.06 & $0.52^{* * *}$ & 0.24 & 0.33 \\
\hline & $T_{\min }$ & 0.28 & $0.48^{* *}$ & 0.25 & $-0.54^{* * *}$ & -0.23 & $-0.46^{* *}$ & 0.20 \\
\hline \multirow{5}{*}{ Meadow steppe } & $P$ & 0.26 & 0.30 & 0.31 & -0.14 & $-0.44^{* *}$ & -0.03 & 0.32 \\
\hline & PET & 0.12 & 0.02 & -0.25 & 0.07 & $0.49^{* *}$ & -0.05 & 0.08 \\
\hline & $T_{\text {mean }}$ & $0.38^{*}$ & $0.49^{* *}$ & -0.12 & 0.03 & 0.13 & 0.07 & 0.33 \\
\hline & $T_{\max }$ & 0.30 & $0.38^{*}$ & -0.16 & 0.07 & 0.33 & -0.03 & 0.30 \\
\hline & $T_{\min }$ & $0.50^{* *}$ & $0.53^{* * *}$ & 0.03 & 0.01 & $-0.38^{*}$ & 0.12 & $0.38^{*}$ \\
\hline \multirow{5}{*}{ Typical steppe } & $P$ & 0.30 & $0.63^{* * *}$ & $0.54^{* * *}$ & 0.19 & 0.10 & -0.16 & 0.23 \\
\hline & PET & -0.11 & $-0.38^{*}$ & $-0.47^{* *}$ & -0.31 & -0.29 & 0.01 & 0.05 \\
\hline & $T_{\text {mean }}$ & 0.21 & 0.29 & $-0.37^{*}$ & -0.15 & -0.21 & 0.23 & 0.25 \\
\hline & $T_{\max }$ & 0.10 & 0.11 & $-0.41^{* *}$ & -0.19 & -0.19 & 0.22 & 0.22 \\
\hline & $T_{\min }$ & 0.34 & $0.45^{* *}$ & -0.27 & 0.02 & -0.17 & 0.22 & 0.30 \\
\hline \multirow{5}{*}{ Desert steppe } & $P$ & 0.22 & $0.72^{* * *}$ & $0.55^{* * *}$ & $0.60^{* * *}$ & $0.56^{* * *}$ & 0.02 & 0.20 \\
\hline & PET & -0.30 & $-0.58^{* * *}$ & $-0.39^{*}$ & $-0.47^{* *}$ & $-0.55^{* * *}$ & -0.25 & -0.30 \\
\hline & $T_{\text {mean }}$ & -0.30 & -0.20 & $-0.50^{* *}$ & -0.33 & -0.30 & -0.00 & -0.15 \\
\hline & $T_{\max }$ & $-0.34^{*}$ & -0.30 & $-0.49^{* *}$ & -0.32 & -0.32 & 0.01 & -0.14 \\
\hline & $T_{\min }$ & -0.21 & 0.19 & $-0.37^{*}$ & -0.160 & -0.13 & 0.00 & -0.14 \\
\hline \multirow{5}{*}{ Desert } & $P$ & -0.21 & 0.01 & 0.09 & $-0.36^{*}$ & -0.04 & -0.09 & -0.05 \\
\hline & PET & 0.10 & 0.08 & 0.01 & 0.24 & 0.07 & -0.16 & -0.29 \\
\hline & $T_{\text {mean }}$ & -0.19 & -0.04 & 0.20 & 0.11 & 0.11 & -0.17 & $-0.45^{* *}$ \\
\hline & $T_{\max }$ & -0.10 & 0.11 & 0.27 & 0.20 & 0.18 & -0.09 & -0.33 \\
\hline & $T_{\min }$ & -0.24 & -0.22 & 0.11 & -0.12 & -0.02 & -0.24 & $-0.56^{* * *}$ \\
\hline \multirow{5}{*}{ Crop } & $P$ & 0.21 & $0.36^{*}$ & $0.37^{*}$ & 0.00 & -0.21 & -0.22 & 0.17 \\
\hline & PET & -0.00 & -0.21 & 0.07 & -0.12 & 0.04 & 0.08 & 0.06 \\
\hline & $T_{\text {mean }}$ & -0.07 & -0.10 & $-0.43^{* *}$ & 0.17 & 0.20 & $0.40^{* *}$ & 0.16 \\
\hline & $T_{\max }$ & -0.05 & -0.17 & $-0.45^{* *}$ & 0.12 & 0.21 & $0.46^{* *}$ & 0.12 \\
\hline & $T_{\min }$ & -0.02 & -0.01 & $-0.43^{* *}$ & 0.28 & 0.12 & $0.36^{*}$ & 0.15 \\
\hline
\end{tabular}

${ }^{* * *},{ }^{* *}$, and ${ }^{*}$ indicate $P<0.01, P<0.05$ and $P<0.1$, respectively; Bolded numbers denote larger correlation coefficients between the monthly mean NDVI and the corresponding climate variables in the same month, compared with those for climate variables in the preceding month.

in extremely arid conditions, temperature-associated drought generally reduces water availability for vegetation growth, which offsets slight changes in precipitation, leading to a limited effect on vegetation growth $[22,59]$.

For cropland, growing season NDVI only showed a significant relationship with PET $(R=-0.58, P<0.01)$. Nevertheless, considering the different crop growth periods, we calculated the correlation coefficients between NDVI and corresponding climate variables during April to June and July to September, respectively, and nonsignificant correlation was observed. This can be evidenced by ground-based observations. Several studies have revealed that grain yield in this region is probably because of intensive human management, such as fertilization and changing crop type [54, 61, 62].

\subsection{The Responses of Monthly NDVI to Climate Changes}

3.3.1. The Responses of Monthly NDVI to Climate Changes in the Same Time. The relationship of the monthly NDVI to climate variables was complicated and varied temporally among the biomes (Table 2). The forest NDVI was significantly and positively related to $T_{\text {mean }}, T_{\max }$, and $T_{\min }$ in April and May, but negatively to $T_{\min }$ in July, August, and September $(R=-0.54, P<0.01 ; R=-0.23, P=$ 0.26 ; and $R=-0.46, P<0.05$, resp.). These findings suggest that an increase in temperature may increase forest growth at the beginning of the growing period, but the minimum temperature increase may depress forest growth in the middle of the growing period. In agreement with previous studies, the large increase in NDVI occurred in the early growing season due to a large temperature rise and advanced growing season [63]. The forest NDVI correlated significantly and negatively with $P$ in July $(R=-0.38$, $P<0.1)$ and August $(R=-0.44, P<0.05)$, whereas it significantly and positively related to PET, except in June $(R=0.13, P=0.54)$ and October $(R=-0.05, P=$ 0.82 ), indicating that excess rainfall in summer can be an 
important limiting factor for forest growth. This is consistent with the results of Fang et al., who reported that forest growth tended to decrease with an increase of precipitation in a relatively cold condition [64]. NDVI for meadow steppe was positively correlated with temperature over almost all of the growing season months, and significantly in April and May. However, NDVI showed a positive correlation with $P$ in April, May, June, and October, but only a significant negative correlation in August $(R=-0.44, P<0.05)$. In comparison, although NDVI was positively correlated with $P$, and negatively related to PET during most growing months for both typical and desert steppe, there was an opposite trend in correlations between NDVI and temperature in April, May, and October. This difference response of steppes to monthly climate change may also be highly correlated with the eastto-west water-temperature gradient. From east to west (i.e., from meadow steppe, typical steppe to desert steppe), the correlation between monthly NDVI and precipitation was strengthened as aridity increased, whereas monthly NDVI was more weakly related to temperature with temperature rising [22].

The NDVI of the temperate desert did not correlate well with climate variables for any month, but most of the correlations between NDVI and $T_{\text {mean }}, T_{\max }$, and $T_{\text {min }}$ were negative in April, May, September, and October, and especially in October. For cropland, the monthly NDVI was positively related to $P$, but negatively to $T_{\text {mean }}, T_{\max }$, and $T_{\min }$ in April, May, and June, and most significantly in June $(R=0.37, P<0.1 ; R=-0.43, P<0.05 ; R=-0.45$, $P<0.05$; and $R=-0.43, P<0.05$, resp.), whereas the opposite relationships occurred in July, August, September, and October, but particularly in September $(R=-0.22, P=$ $0.29 ; R=0.40, P<0.05 ; R=-0.46, P<0.05$; and $R=-0.36$, $P<0.05$, resp.).

3.3.2. The Response of Monthly NDVI to Climate Change in the Previous Month. Although the monthly NDVI had a similar pattern to that of the climate variables, the monthly peak NDVI was not always coupled with those climatic factors (Figure 2). This discrepancy may suggest a lagged response of NDVI to change in climate [16]. To illustrate and analyze this lagged response of vegetation growth, we also calculated correlation coefficients between monthly NDVI and climatic variables from the preceding month (Table 3). The strength of the relationship varied, however, depending on the biomes and climate variables. For forest, significantly positive correlations were found between the NDVI value in April, May, and September, and PET, $T_{\text {mean }}, T_{\text {max }}$, and $T_{\text {min }}$ from the preceding month, whereas the NDVI value in April was negatively related to antecedent $P(R=-0.51$, $P<0.01)$. This implies that temperature and potential evapotranspiration in the preceding month are beneficial to forest growth at the beginning and end of the growing season, whereas precipitation during the previous month can depress growth in early spring. The weakly response of forest to preceding $P$ can result from the deeper-rooted system that can maintain amount of moisture during dry periods by absorbing water from the deeper soil and adequate precipitation [52].
Similarly, for the three steppe types, most NDVI values in April and May were positively correlated with $T_{\text {mean }}$, $T_{\max }$, and $T_{\min }$ in the previous month, implying that higher temperatures in the preceding month could stimulate grass growth at the beginning of the growing season. In comparison, there were positive correlations between $P$ from the preceding month and monthly NDVI values during the whole growing season (except April for meadow steppe), whereas an almost opposite relationship between NDVI values and corresponding PET appeared at the same time. In addition, during the latter period of the growing season, correlations between the monthly NDVI and climate variables in the previous month were always stronger than the correlations with no time lag, suggesting that the antecedent climate conditions may be critical to grass growth in the latter part of the growing season (Tables 2 and 3). For the cropland, the lagged response of monthly NDVI to changes in climate was not well observed as for the other vegetation types, which is inconsistent with those who concluded that crop seemed to respond more quickly to precipitation than grasslands due to more shallow-rooted system [65]. The difference may be ascribed to different time scale. In this study, we just focused on one month lag effect and could not to detect lag times less than 30 days.

Monthly NDVI increases at the beginning of the growing season (in May for forest, and in April for steppes) were greatly responsible for the growing season NDVI changes, which were almost all strongly and positively related to the current and preceding month's $T_{\text {mean }}, T_{\max }$, and $T_{\text {min }}$ (Tables 2 and 3). It is possible that, in relatively high latitude regions (forest, as well as meadow and typical steppe areas) where the temperature is relatively low (Figure 2), vegetation growth is highly sensitive to temperature change at the beginning of the growing season $[43,66]$. Spring warming can lower levels of frost damage, thaw out the frozen soil, advance the beginning of the growing season, promote plant photosynthesis, and thereby boost vegetation growth $[67,68]$. This is partly confirmed by the negative correlation between corresponding precipitation and NDVI in relatively colder regions (Table 2), because spring rainfall can lower temperatures. The disparity between the larger increase at the beginning of the growing season in May for forest, and not in April as for the steppes, can be attributed to the later arrival of spring. Previous studies suggest that the period with daily mean temperatures consistently above $5^{\circ} \mathrm{C}$ is generally regarded as the growing season for trees [33], with temperatures above $0^{\circ} \mathrm{C}$ necessary for grass growth [69]. Consequently, the start of the growing season in the steppe regions may be one month ahead of that in the forested areas (on Julian days 79 and 111, resp.).

NDVI variability in spring (April and May) was positively related to $T_{\text {mean }}, T_{\max }$, and $T_{\text {min }}$ from the preceding month, but almost always negatively related to the temperature range in the current month for desert steppe and desert. The pattern of these relationships may result mainly from differences in regional climate conditions. In the desert steppe and desert regions, where water resources are seriously limited (the ratio of monthly PET to $P$ in April and May is 48.43 and 16.65, resp., for desert steppe, and 93.11 and 34.03, resp., for desert; Figure 2), the heat or water stress induced by climate 
TABLE 3: Correlation coefficients between monthly mean NDVI and $P, P E T, T_{\text {mean }}, T_{\max }$, and $T_{\min }$ in the preceding month for different vegetation types.

\begin{tabular}{|c|c|c|c|c|c|c|c|c|}
\hline \multirow{2}{*}{ Vegetation types } & \multirow{2}{*}{ Climate variables } & \multicolumn{7}{|c|}{ Correlation coefficient } \\
\hline & & 4 & 5 & 6 & 7 & 8 & 9 & 10 \\
\hline \multirow{5}{*}{ Forest } & $P$ & $-0.51^{* * *}$ & 0.11 & 0.25 & -0.05 & -0.21 & -0.19 & 0.14 \\
\hline & PET & $0.63^{* * *}$ & 0.32 & -0.24 & -0.10 & 0.32 & $0.49^{* *}$ & 0.01 \\
\hline & $T_{\text {mean }}$ & $0.40^{*}$ & $0.48^{* *}$ & -0.20 & 0.01 & -0.07 & $0.35^{*}$ & -0.06 \\
\hline & $T_{\max }$ & $0.45^{* *}$ & $0.36^{*}$ & -0.32 & -0.03 & 0.09 & $0.45^{* *}$ & -0.09 \\
\hline & $T_{\min }$ & $0.37^{*}$ & $0.49^{* *}$ & 0.07 & 0.14 & -0.28 & -0.09 & 0.03 \\
\hline \multirow{5}{*}{ Meadow steppe } & $P$ & -0.05 & 0.25 & $0.50^{* *}$ & 0.03 & 0.01 & $0.57^{* * *}$ & $0.48^{* *}$ \\
\hline & PET & $0.51^{* *}$ & 0.16 & -0.19 & -0.27 & -0.01 & $-0.48^{* *}$ & $-0.36^{*}$ \\
\hline & $T_{\text {mean }}$ & 0.29 & 0.33 & -0.03 & 0.06 & 0.15 & -0.30 & 0.07 \\
\hline & $T_{\max }$ & 0.30 & 0.33 & -0.16 & 0.02 & 0.08 & $-0.40^{* *}$ & -0.14 \\
\hline & $T_{\min }$ & 0.28 & $0.35^{*}$ & 0.14 & 0.15 & 0.25 & 0.11 & $0.37^{*}$ \\
\hline \multirow{5}{*}{ Typical steppe } & $P$ & 0.04 & $0.50^{* *}$ & $0.39^{*}$ & 0.20 & $0.53^{* * *}$ & $0.66^{* * *}$ & 0.22 \\
\hline & PET & $0.37^{*}$ & -0.14 & $-0.41^{* *}$ & $-0.45^{* *}$ & $-0.48^{* *}$ & $-0.74^{* * *}$ & -0.17 \\
\hline & $T_{\text {mean }}$ & 0.33 & $0.41^{* *}$ & 0.15 & -0.20 & 0.00 & $-0.51^{* *}$ & 0.19 \\
\hline & $T_{\max }$ & $0.36^{*}$ & $0.37^{*}$ & 0.01 & -0.22 & -0.15 & $-0.59^{* * *}$ & 0.09 \\
\hline & $T_{\min }$ & 0.33 & $0.48^{* *}$ & 0.29 & -0.14 & 0.32 & -0.15 & 0.30 \\
\hline \multirow{5}{*}{ Desert steppe } & $P$ & 0.22 & $0.71^{* * *}$ & $0.64^{* * *}$ & $0.51^{* * *}$ & $0.71^{* * *}$ & $0.74^{* * *}$ & 0.04 \\
\hline & PET & 0.16 & $-0.34^{*}$ & $-0.71^{* * *}$ & -0.33 & $-0.40 * *$ & $-0.67^{* * *}$ & -0.23 \\
\hline & $T_{\text {mean }}$ & 0.30 & 0.21 & -0.05 & $-0.41^{* *}$ & 0.02 & $-0.44^{* *}$ & 0.01 \\
\hline & $T_{\max }$ & 0.29 & 0.14 & -0.24 & $-0.42^{* *}$ & -0.07 & $-0.47^{* *}$ & 0.04 \\
\hline & $T_{\min }$ & 0.30 & $0.35^{*}$ & 0.27 & -0.27 & 0.29 & -0.21 & 0.03 \\
\hline \multirow{5}{*}{ Desert } & $P$ & 0.13 & -0.04 & $0.68^{* * *}$ & 0.12 & 0.14 & $0.40^{* *}$ & -0.18 \\
\hline & PET & 0.01 & -0.11 & $-0.44^{* *}$ & -0.02 & 0.15 & -0.27 & -0.12 \\
\hline & $T_{\text {mean }}$ & 0.13 & 0.18 & -0.09 & -0.08 & 0.26 & 0.02 & 0.04 \\
\hline & $T_{\max }$ & 0.17 & 0.17 & -0.16 & -0.05 & 0.25 & -0.01 & 0.09 \\
\hline & $T_{\min }$ & 0.10 & 0.18 & 0.13 & -0.06 & 0.27 & 0.05 & -0.08 \\
\hline \multirow{5}{*}{ Crop } & $P$ & 0.27 & 0.08 & 0.09 & 0.02 & 0.11 & 0.13 & 0.21 \\
\hline & PET & -0.19 & 0.04 & $-0.43^{* *}$ & -0.31 & -0.24 & -0.32 & -0.15 \\
\hline & $T_{\text {mean }}$ & 0.10 & 0.23 & -0.23 & 0.23 & 0.32 & -0.02 & -0.03 \\
\hline & $T_{\max }$ & 0.10 & 0.26 & -0.29 & 0.20 & 0.20 & -0.09 & -0.09 \\
\hline & $T_{\min }$ & 0.11 & 0.20 & -0.14 & 0.28 & $0.52^{* * *}$ & 0.15 & 0.04 \\
\hline
\end{tabular}

${ }^{* * *},{ }^{* *}$, and ${ }^{*}$ indicate $P<0.01, P<0.05$, and $P<0.1$, respectively; Bolded numbers denote larger correlation coefficients between the monthly mean NDVI and the corresponding climate variables in the preceding month, compared with those for climate variables in the same month.

change can adversely affect grass germination and initial growth $[27,70]$, despite the fact that previous warming can promote germination. These also support the other findings, which report that onset dates of green-up are delayed by the warming trend in the desert steppe [71].

\section{Conclusion}

Based on the normalized difference vegetation index (NDVI), we have investigated the growing season and monthly NDVI trends and their relationships with climate variables for six biomes in Inner Mongolia over the period 19822006. Our results indicated that the growing season NDVI generally increased over the past 25 years for all biomes. The pronounced increase was found in cropland, which almost certainly stemmed from the primary crop type change and the advance of agricultural management. Changes in climate likely functioned as the important controller for interannual variations in natural vegetation activity. The growing season NDVI was positively related to potential evapotranspiration and temperature, but negatively correlated with higher precipitation for the forest. In contrast, a positive (negative) correlation between NDVI and precipitation (potential evapotranspiration) existed in the steppes and desert. Additionally, monthly changes in climate seemed to influence plant growth in nonlinear fashions at the biome level, depending on times, climate variables, and biome types. Warming-related NDVI at the beginning of the growing season largely contributed to the NDVI increase during the growing season for forest, meadow steppe, and typical steppe but constrained the NDVI increase for desert steppe, desert, and crop. Moreover, our results also suggested that there were complicated one-month lags in vegetation responses to climate changes. However, although this study would greatly improve understanding of the complicated responses of vegetation to climate changes in Inner Mongolia, we could 
not determine the relative contribution of these factors. How to separate the contributions from different driving forces remains a big challenge for further studies.

\section{Conflict of Interests}

The authors declare that there is no conflict of interests regarding the publication of this paper.

\section{Acknowledgment}

This study was supported by the National Scientific Technical Supporting Programs during the 12th Five-year Plan of China (2012BAC19B04) and National Basic Research Program of China (2011CB403206).

\section{References}

[1] T. G. Huntington, "Climate change, growing season length, and transpiration: plant response could alter hydrologic regime," Plant Biology, vol. 6, no. 6, pp. 651-653, 2004.

[2] E. Post, M. C. Forchhammer, M. S. Bret-Harte et al., "Ecological dynamics across the arctic associated with recent climate change," Science, vol. 325, no. 5946, pp. 1355-1358, 2009.

[3] F. Tao, S. Zhang, and Z. Zhang, "Changes in rice disasters across China in recent decades and the meteorological and agronomic causes," Regional Environmental Change, vol. 13, no. 4, pp. 743759, 2013.

[4] C. J. Tucker, D. A. Slayback, J. E. Pinzon, S. O. Los, R. B. Myneni, and M. G. Taylor, "Higher northern latitude normalized difference vegetation index and growing season trends from 1982 to 1999," International Journal of Biometeorology, vol. 45, no. 4, pp. 184-190, 2001.

[5] S. Wan, D. Hui, L. Wallace, and Y. Luo, "Direct and indirect effects of experimental warming on ecosystem carbon processes in a tallgrass prairie," Global Biogeochemical Cycles, vol. 19, no. 2, Article ID GB2014, pp. 1-13, 2005.

[6] S. Chen, G. Lin, J. Huang, and G. D. Jenerette, "Dependence of carbon sequestration on the differential responses of ecosystem photosynthesis and respiration to rain pulses in a semiarid steppe," Global Change Biology, vol. 15, no. 10, pp. 2450-2461, 2009.

[7] M. U. F. Kirschbaum, "The temperature dependence of soil organic matter decomposition, and the effect of global warming on soil organic C storage," Soil Biology and Biochemistry, vol. 27, no. 6, pp. 753-760, 1995.

[8] D. S. Ojima, W. J. Parton, D. S. Schimel, J. M. O. Scurlock, and T. G. F. Kittel, "Modeling the effects of climatic and CO2 changes on grassland storage of soil C," Water, Air, and Soil Pollution, vol. 70, no. 1-4, pp. 643-657, 1993.

[9] I. M. D. Maclean and R. J. Wilson, "Recent ecological responses to climate change support predictions of high extinction risk," Proceedings of the National Academy of Sciences of the United States of America, vol. 108, no. 30, pp. 12337-12342, 2011.

[10] R. Warren, J. Price, A. Fischlin, S. de la Nava Santos, and G. Midgley, "Increasing impacts of climate change upon ecosystems with increasing global mean temperature rise," Climatic Change, vol. 106, no. 2, pp. 141-177, 2011.

[11] E. Lugato and A. Berti, "Potential carbon sequestration in a cultivated soil under different climate change scenarios: a modelling approach for evaluating promising management practices in north-east Italy," Agriculture, Ecosystems and Environment, vol. 128, no. 1-2, pp. 97-103, 2008.

[12] D. Zhao, S. Wu, and Y. Yin, "Responses of terrestrial ecosystems' net primary productivity to future regional climate change in China," PloS ONE, vol. 8, no. 4, Article ID e60849, 2013.

[13] X. Wang, S. Piao, P. Ciais et al., "Spring temperature change and its implication in the change of vegetation growth in North America from 1982 to 2006," Proceedings of the National Academy of Sciences of the United States of America, vol. 108, no. 4, pp. 1240-1245, 2011.

[14] J. Harte and R. Shaw, "Shifting dominance within a montane vegetation community: results of a climate-warming experiment," Science, vol. 267, no. 5199, pp. 876-880, 1995.

[15] H. A. Barbosa, A. R. Huete, and W. E. Baethgen, "A 20-year study of NDVI variability over the Northeast Region of Brazil," Journal of Arid Environments, vol. 67, no. 2, pp. 288-307, 2006.

[16] S. Piao, J. Fang, L. Zhou et al., "Interannual variations of monthly and seasonal normalized difference vegetation index (NDVI) in China from 1982 to 1999," Journal of Geophysical Research D, vol. 108, no. 14, pp. 1-13, 2003.

[17] A. K. Knapp and M. D. Smith, "Variation among biomes in temporal dynamics of aboveground primary production," Science, vol. 291, no. 5503, pp. 481-484, 2001.

[18] S. Sarkar and M. Kafatos, "Interannual variability of vegetation over the Indian sub-continent and its relation to the different meteorological parameters," Remote Sensing of Environment, vol. 90, no. 2, pp. 268-280, 2004.

[19] A. Kawabata, K. Ichii, and Y. Yamaguchi, "Global monitoring of interannual changes in vegetation activities using NDVI and its relationships to temperature and precipitation," International Journal of Remote Sensing, vol. 22, no. 7, pp. 1377-1382, 2001.

[20] X. Zeng, P. Rao, R. S. DeFries, and M. C. Hansen, "Interannual variability and decadal trend of global fractional vegetation cover from 1982 to 2000," Journal of Applied Meteorology, vol. 42, no. 10, pp. 1525-1530, 2003.

[21] C. S. Potter, S. Klooster, and V. Brooks, "Interannual variability in terrestrial net primary production: exploration of trends and controls on regional to global scales," Ecosystems, vol. 2, no. 1, pp. 36-48, 1999.

[22] S. Piao, A. Mohammat, J. Fang, Q. Cai, and J. Feng, "NDVIbased increase in growth of temperate grasslands and its responses to climate changes in China," Global Environmental Change, vol. 16, no. 4, pp. 340-348, 2006.

[23] I. Fabricante, M. Oesterheld, and J. M. Paruelo, "Annual and seasonal variation of NDVI explained by current and previous precipitation across Northern Patagonia," Journal of Arid Environments, vol. 73, no. 8, pp. 745-753, 2009.

[24] R. D. Alward, J. K. Detling, and D. G. Milchunas, "Grassland vegetation changes and nocturnal global warming," Science, vol. 283, no. 5399, pp. 229-231, 1999.

[25] J. Szilagyi, D. C. Rundquist, D. C. Gosselin, and M. B. Parlange, "NDVI relationship to monthly evaporation," Geophysical Research Letters, vol. 25, no. 10, pp. 1753-1756, 1998.

[26] W. Yang, L. Yang, and J. W. Merchant, "An assessment of AVHRR/NDVI-ecoclimatological relations in Nebraska, U.S.A.," International Journal of Remote Sensing, vol. 18, no. 10, pp. 2161-2180, 1997.

[27] L. Yang, B. K. Wylie, L. L. Tieszen, and B. C. Reed, "An analysis of relationships among climate forcing and time-integrated NDVI of grasslands over the U.S. northern and central Great Plains," Remote Sensing of Environment, vol. 65, no. 1, pp. 25-37, 1998. 
[28] X. Zhao, K. Tan, S. Zhao, and J. Fang, "Changing climate affects vegetation growth in the arid region of the northwestern China," Journal of Arid Environments, vol. 75, no. 10, pp. 946-952, 2011.

[29] B. Li, S. Tao, and R. W. Dawson, "Relations between AVHRR NDVI and ecoclimatic parameters in China," International Journal of Remote Sensing, vol. 23, no. 5, pp. 989-999, 2002.

[30] B. H. Braswell, D. S. Schimel, E. Linder, and B. Moore III, "The response of global terrestrial ecosystems to interannual temperature variability," Science, vol. 278, no. 5339, pp. 870-872, 1997.

[31] Y. Yang, J. Xu, Y. Hong, and G. Lv, “The dynamic of vegetation coverage and its response to climate factors in Inner Mongolia, China," Stochastic Environmental Research and Risk Assessment, vol. 26, no. 3, pp. 357-373, 2012.

[32] G. Zhang, Y. Kang, G. Han, and K. Sakurai, "Effect of climate change over the past half century on the distribution, extent and NPP of ecosystems of Inner Mongolia," Global Change Biology, vol. 17, no. 1, pp. 377-389, 2011.

[33] B. Liu, M. Henderson, Y. Zhang, and M. Xu, "Spatiotemporal change in China's climatic growing season: 1955-2000," Climatic Change, vol. 99, no. 1-2, pp. 93-118, 2010.

[34] W. Qian and X. Lin, "Regional trends in recent temperature indices in China," Climate Research, vol. 27, no. 2, pp. 119-134, 2004.

[35] B. Liu, M. Xu, M. Henderson, Y. Qi, and Y. Li, “Taking China's temperature: daily range, warming trends, and regional variations, 1955-2000," Journal of Climate, vol. 17, no. 22, pp. 4453-4462, 2004.

[36] N. Lu, B. Wilske, J. Ni, R. John, and J. Chen, "Climate change in Inner Mongolia from 1955 to 2005-trends at regional, biome and local scales," Environmental Research Letters, vol. 4, no. 4, Article ID 045006, 2009.

[37] S. Brogaard, M. Runnström, and J. W. Seaquist, "Primary production of Inner Mongolia, China, between 1982 and 1999 estimated by a satellite data-driven light use efficiency model," Global and Planetary Change, vol. 45, no. 4, pp. 313-332, 2005.

[38] L. Zhang, Z. Yang, and G. Chen, "Emergy analysis of croppinggrazing system in Inner Mongolia Autonomous Region, China," Energy Policy, vol. 35, no. 7, pp. 3843-3855, 2007.

[39] S. Wu, Q. Yang, and D. Zheng, "Delineation of eco-geographic regional system of China," Journal of Geographical Sciences, vol. 13, no. 3, pp. 309-315, 2003.

[40] J. Fang, S. Piao, J. He, and W. Ma, "Increasing terrestrial vegetation activity in China, 1982-1999," Science in China C, vol. 47, no. 3, pp. 229-240, 2004.

[41] B. N. Holben, "Characteristics of maximum-value composite images from temporal AVHRR data," International Journal of Remote Sensing, vol. 7, no. 11, pp. 1417-1434, 1986.

[42] Z. P. Wang, X. G. Han, G. G. Wang, Y. Song, and J. Gulledge, "Aerobic methane emission from plants in the Inner Mongolia steppe," Environmental Science and Technology, vol. 42, no. 1, pp. 62-68, 2008.

[43] S. Piao, X. Wang, P. Ciais, B. Zhu, T. Wang, and J. Liu, "Changes in satellite-derived vegetation growth trend in temperate and boreal Eurasia from 1982 to 2006," Global Change Biology, vol. 17, no. 10, pp. 3228-3239, 2011.

[44] S. Peng, A. Chen, L. Xu et al., "Recent change of vegetation growth trend in China," Environmental Research Letters, vol. 6, no. 4, Article ID 044027, 2011.
[45] Y. Yin, S. Wu, and E. Dai, "Determining factors in potential evapotranspiration changes over China in the period 19712008," Chinese Science Bulletin, vol. 55, no. 29, pp. 3329-3337, 2010.

[46] Editorial Board of Vegetation Map of China, Vegetation Atlas of China, Science Press, Beijing, China, 2001.

[47] Editorial Board of Rangeland Resources of China, Rangeland Resources of China, Science Press, Beijing, China, 1996.

[48] J. Liu, M. Liu, D. Zhuang, Z. Zhang, and X. Deng, "Study on spatial pattern of land-use change in China during 1995-2000," Science in China, Series D, vol. 46, no. 4, pp. 373-384, 2003.

[49] B. Liu, Y. Huang, J. Fu, and D. Jiang, "Analysis on Spatiotemporal change and driving forces of land use in Tianjin Harbor," Journal of Geo-Information Science, vol. 14, no. 2, pp. 270-278, 2012.

[50] X. Zhang and J. Zhu, "Variations in fractional vegetation coverage over Eastern China during 1982-2006," Climatic and Environmental Research, no. 3, pp. 365-374, 2013.

[51] G. Bao, Z. Qin, Y. Bao, and Y. Zhou, "Spatial-temporal change of vegetation cover in Mongolian Platean during 1982-2006," Journal of Desert Research, vol. 33, no. 3, pp. 918-927, 2013.

[52] D. Mao, Z. Wang, L. Luo, and C. Ren, "Integrating AVHRR and MODIS data to monitor NDVI changes and their relationships with climatic parameters in Northeast China," International Journal of Applied Earth Observation and Geoinformation, vol. 18, pp. 528-536, 2012.

[53] X. Wang, Y. Li, G. Cui, X. Wu, M. Yu, and W. Ma, "Review of wheat production in inner Mongolia and its actuality analysis," Inner Mongolia Agriculture Science and Technology, no. 6, pp. $5-6,2010$.

[54] R. Luo, B. Zhang, J. Gao, Z. Wang, J. Sun, and X. Yu, "Climate change impacts on corn production as evidenced by a model and historical yields in Inner Mongolia, China," Journal of Food, Agriculture \& Environment, vol. 10, no. 2, pp. 976-983, 2012.

[55] K. Ichii, A. Kawabata, and Y. Yamaguchi, "Global correlation analysis for NDVI and climatic variables and NDVI trends: 1982-1990," International Journal of Remote Sensing, vol. 23, no. 18, pp. 3873-3878, 2002.

[56] E. S. Euskirchen, A. D. McGuire, D. W. Kicklighter et al., "Importance of recent shifts in soil thermal dynamics on growing season length, productivity, and carbon sequestration in terrestrial high-latitude ecosystems," Global Change Biology, vol. 12, no. 4, pp. 731-750, 2006.

[57] T. A. Black, W. J. Chen, A. G. Barr et al., "Increased carbon sequestration by a Boreal deciduous forest in years with a warm spring," Geophysical Research Letters, vol. 27, no. 9, pp. 12711274, 2000.

[58] R. R. Nemani, C. D. Keeling, H. Hashimoto et al., "Climatedriven increases in global terrestrial net primary production from 1982 to 1999," Science, vol. 300, no. 5625, pp. 1560-1563, 2003.

[59] M. Zhao and S. W. Running, "Drought-induced reduction in global terrestrial net primary production from 2000 through 2009," Science, vol. 329, no. 5994, pp. 940-943, 2010.

[60] C. J. Tucker, H. E. Dregne, and W. W. Newcomb, "Expansion and contraction of the Sahara desert from 1980 to 1990," Science, vol. 253, no. 5017, pp. 299-301, 1991.

[61] L. Zhao and L. Duan, "The analysis of main factors affecting grain yield in Inner Mongolia Autonomous Region," Journal of Northwest Sci-Tec University of Agriculture and Forest, vol. 29, no. 4, pp. 77-80, 2001. 
[62] L. Zhang, X. Zhao, D. Zhao, F. Yang, and L. Zhang, "Dynamic analysis of grain production and evaluation of food security of Inner Mongolia," Agricultural Research in the Arid Areas, vol. 28, no. 5, pp. 190-195, 2010.

[63] L. Zhou, C. J. Tucker, R. K. Kaufmann, D. Slayback, N. V. Shabanov, and R. B. Myneni, "Variations in northern vegetation activity inferred from satellite data of vegetation index during 1981 to 1999," Journal of Geophysical Research D, vol. 106, no. 17, pp. 20069-20083, 2001.

[64] J. Fang, S. Piao, L. Zhou et al., "Precipitation patterns alter growth of temperate vegetation," Geophysical Research Letters, vol. 32, no. 21, Article ID L21411, pp. 1-5, 2005.

[65] J. Wang, P. M. Rich, and K. P. Price, "Temporal responses of NDVI to precipitation and temperature in the central Great Plains, USA," International Journal of Remote Sensing, vol. 24, no. 11, pp. 2345-2364, 2003.

[66] S. Tanja, F. Berninger, T. Vesala et al., "Air temperature triggers the recovery of evergreen boreal forest photosynthesis in spring," Global Change Biology, vol. 9, no. 10, pp. 1410-1426, 2003.

[67] A. D. Richardson, T. A. Black, P. Ciais et al., "Influence of spring and autumn phenological transitions on forest ecosystem productivity," Philosophical Transactions of the Royal Society B, vol. 365, no. 1555, pp. 3227-3246, 2010.

[68] L. R. Welp, J. T. Randerson, and H. P. Liu, "The sensitivity of carbon fluxes to spring warming and summer drought depends on plant functional type in boreal forest ecosystems," Agricultural and Forest Meteorology, vol. 147, no. 3-4, pp. 172185, 2007.

[69] D. J. Moot, W. R. Scott, A. M. Roy, and A. C. Nicholls, "Base temperature and thermal time requirements for germination and emergence of temperate pasture species," New Zealand Journal of Agricultural Research, vol. 43, no. 1, pp. 15-25, 2000.

[70] S. Wan, J. Xia, W. Liu, and S. Niu, "Photosynthetic overcompensation under nocturnal warming enhances grassland carbon sequestration," Ecology, vol. 90, no. 10, pp. 2700-2710, 2009.

[71] F. Yu, K. P. Price, J. Ellis, and P. Shi, "Response of seasonal vegetation development to climatic variations in eastern central Asia," Remote Sensing of Environment, vol. 87, no. 1, pp. 42-54, 2003. 

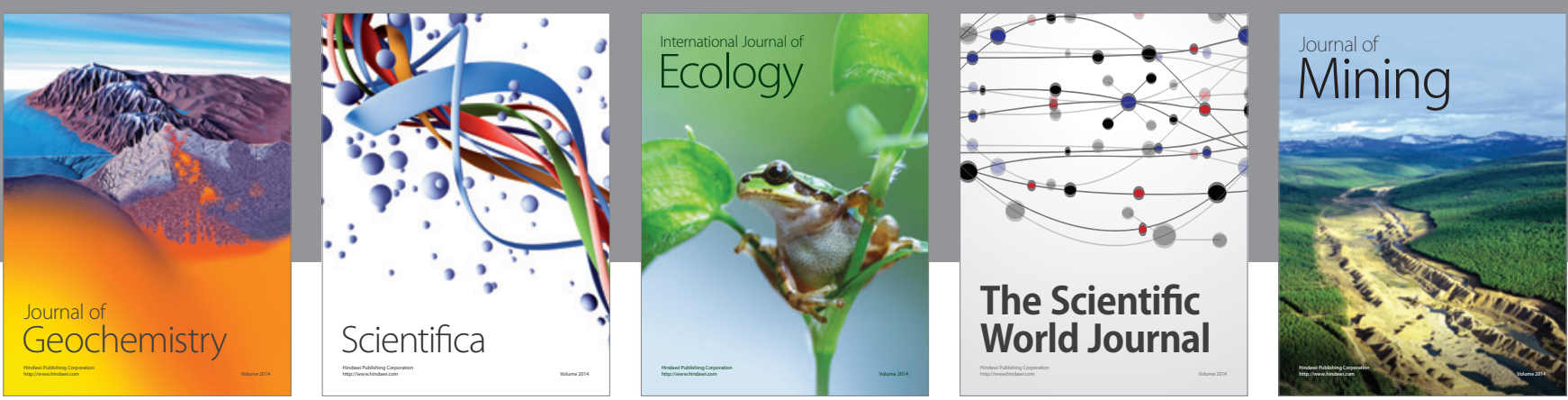

The Scientific World Journal
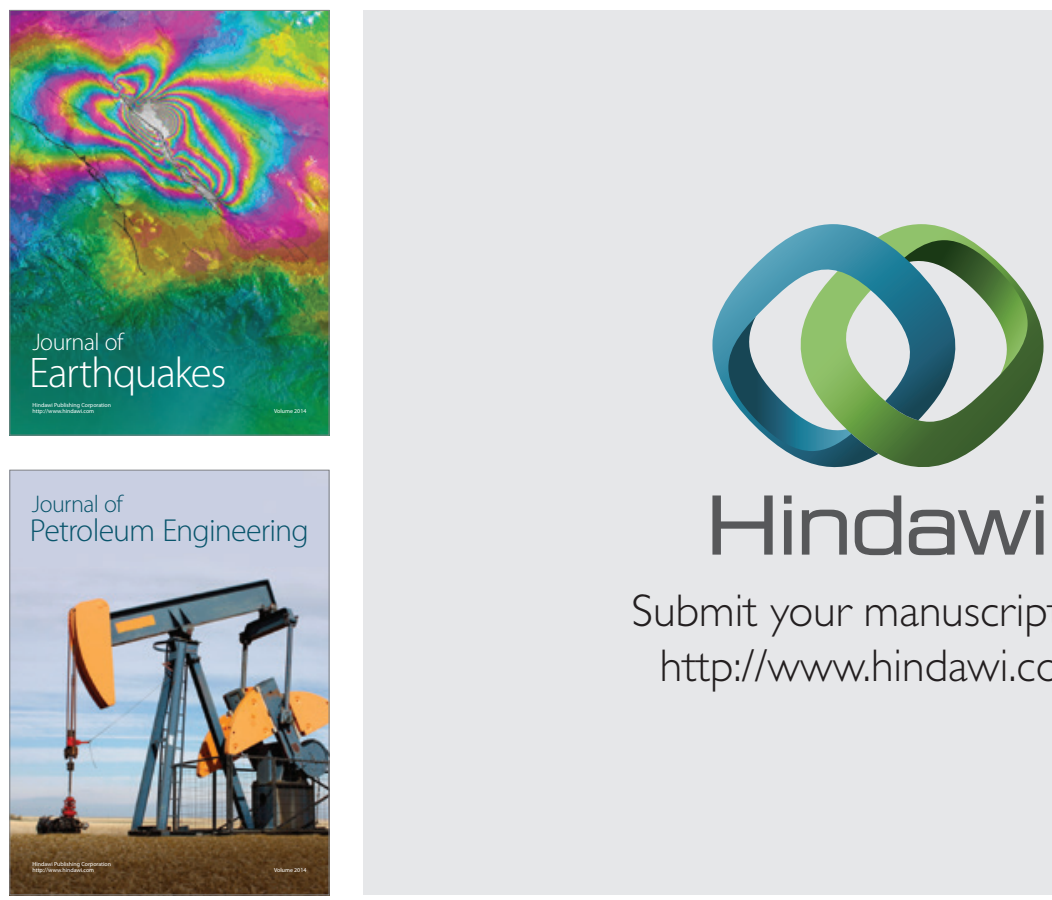

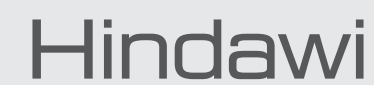

Submit your manuscripts at

http://www.hindawi.com
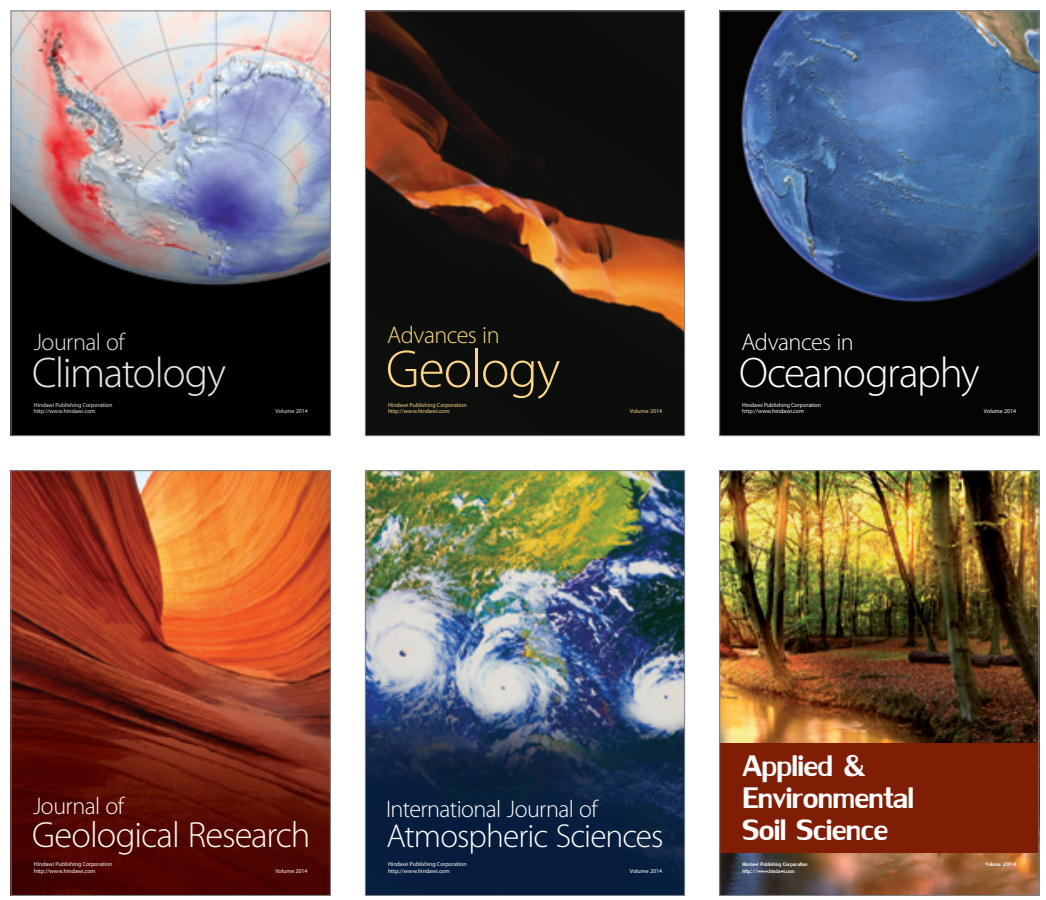
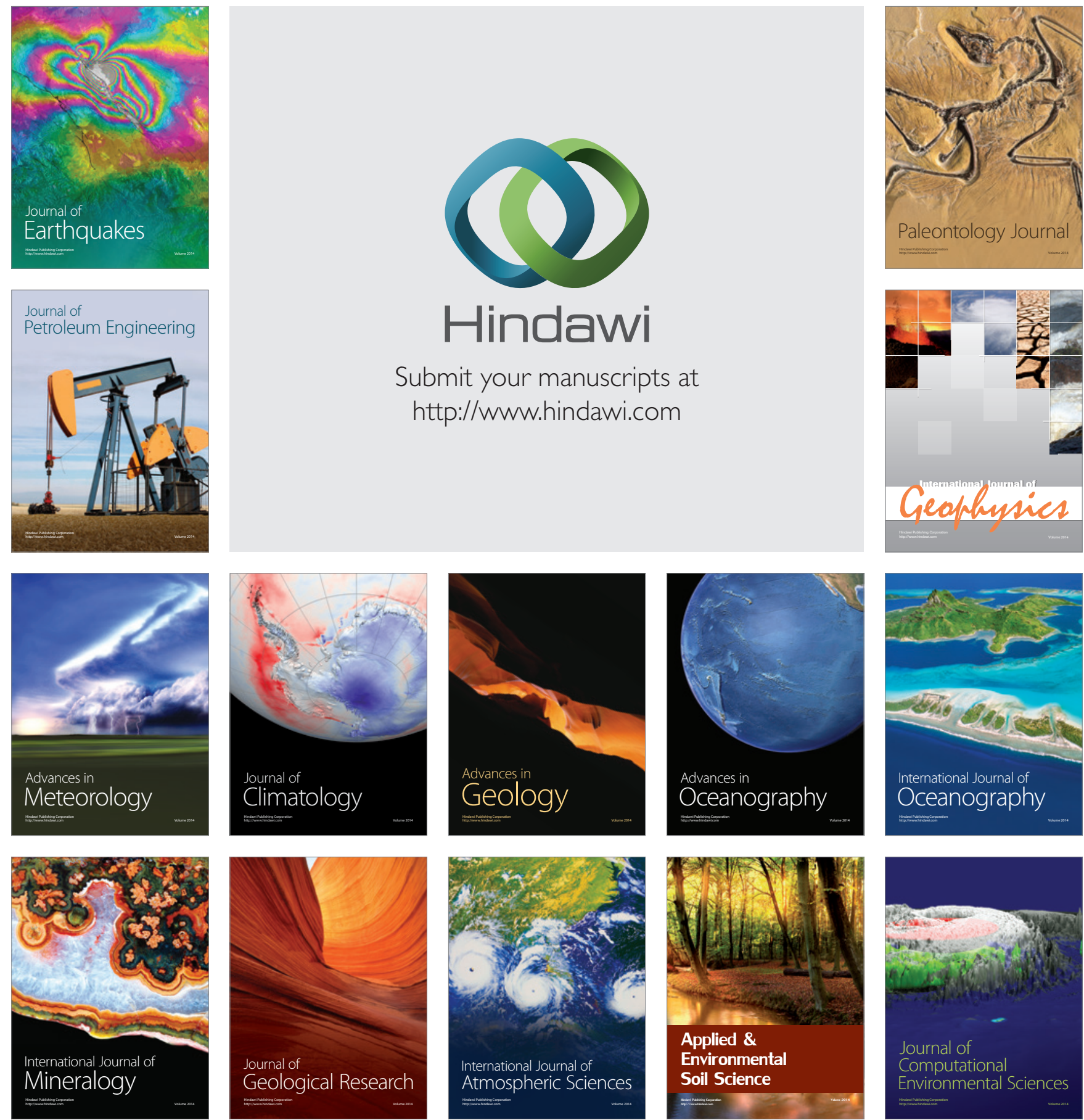